\title{
Empirical Study Of The Relationship Between Energy Consumption And Gross Domestic Product In The U.S.A.
}

Christopher M. Chima, (Email: cchima@ csudh.edu), California State University, Dominguez Hills Rodney Freed, (Email: rfreed@ csudh.edu), California State University, Dominguez Hills

\begin{abstract}
The role of energy in the economy is an important issue. There is a general belief and agreement amongst economists, researchers, analysts, and policymakers, that energy consumption is related to economic activity and plays a key role in the process of economic development. However, the precise nature of this relationship between energy consumption and economic growth remains debatable. While some ambiguity has remained regarding the direction of causation--- whether from energy to economy or from economy to energy --- the importance of the energy -GDP interaction is well recognized. Energy use is a necessary input to economic growth and is also a function of growth. This paper begins with a literature review of the work that has been done to date on the energy-GDP relationship in several countries. Then, an analysis of the historical data for the U.S.A. from 1949 - 2003 is presented along with mathematical models. The contributions from this paper are that first, we clarify that energy conservation policies will not harm the U.S. economy. Second, we employed a macroeconomic model based on Multiple Model Estimation to determine the relationship between energy consumption and GDP in the United States for the stated time period. Our model suggests that the causation goes both ways: from energy to the components of GDP, and from GDP to energy consumption.
\end{abstract}

\section{INTRODUCTION}

There is a general belief and agreement that energy availability and consumption play a key role in the process of economic development. Energy use has been associated with population growth and the expansion of urban centers. Energy use is a key to industrialization and the development of industrial and infrastructural facilities. Roads and transportation networks are among the most energy intensive of these facilities.

While some ambiguity has remained regarding the direction of causation -- whether from energy to economy or from economy to energy - the importance of the energy-economy interaction is well recognized. Energy use is a necessary input to economic growth and is also a function of growth.

Energy has been defined as both a consumer good and an intermediate good (Pierce, 1986). As a consumer good, at the early stages of economic growth, it is possible that consumers will demand and consume more energy as soon as they can acquire the means to do so. It is also possible that the income elasticity of energy demand could become low. This concept can be tested with the intensity of use technique. As an intermediate good, the demand for energy is a derived demand.

The traditional argument is not that energy is merely a consumption good, but that it is an essential input into technological advancement. The substitution of machines and other forms of capital for human labor is an integral part of the process of economic development that requires energy inputs.

Thus, one can view the consumption of large amounts of energy as either a cause or a symptom of economic growth. It is important though to note that the amount of energy consumed depends in part on its availability and 
price. In an era of expensive energy, it will become a priority for policymakers, managers, and researchers to devise ways to economize and use energy wisely and efficiently. This paper addresses these issues with perspectives on the future.

\section{CAUSALITY}

The energy sector has drawn a tremendous amount of attention from academicians, researchers, economists, and policymakers, especially since the oil shocks of the 1970's. The one remarkable effect of this oil shock is the attention it has drawn to the relationship between energy consumption and economic growth, and the consequent impact of rising oil prices on the economies of rich and poor countries alike. Prior to the oil shocks, the world economy had been built and flourished under the presumption of cheap and abundant oil.

During the 1970's, there was a great deal of concern, especially among the developed countries as to whether conservation in energy use would adversely affect economic growth. Thus grew concern amongst policymakers in the industrialized economies regarding the acceptability of energy conservation policies. This concern led to the work of John and Arthur Kraft (1978), in which some light was shed on this issue and provided some answers. They conducted an empirical test, using data for the United States from 1947 to 1974, the purpose of which was to determine the causal relationship between energy consumption and the gross national product (GNP).

There was a widely held view then that there was a constant and unchanging relationship between energy consumption and gross national product. The implied corollary was that energy conservation was an unacceptable policy since it would adversely affect economic activity. Kraft and Kraft concluded from their study that causality was unidirectional, only running from GNP to energy for the post war period, and there was no causality running from energy to GNP. Thus, they concluded that energy conservation is an attractive policy that will not adversely affect economic activity.

This issue of the causal relationship between energy consumption and gross national product became the subject of intense and often heated debate. If energy availability causes increased economic activity, then logically, a reduction in the availability of energy would have serious welfare implications. Thus, Ali T. Arkaca and Thomas V. Long (1980), set forth in their study to show that the causal order suggested by Kraft is a spurious one that is generated by extension of their data sample by two years (1973-1974). They concluded that one cannot differentiate on the basis of annual postwar data between causality from GNP to energy consumption, or from energy consumption to GNP, or the existence of both relations in a feedback mechanism. Arkaca and Long argued that a single equation dynamic regression of energy consumption on GNP cannot be viewed as reflecting a behavioral relation, such as an Engel curve or a demand curve, but rather a solely statistical forecasting relation.

The findings of Arkaca and Long did not contribute in easing the debate which had heated up. Eden S.Yu, and Been-Kwai Hwang (1983) reexamined the causality between energy and GNP by using updated U.S. data for the period 1947 to 1979. Applying Sim's technique (1972), they found no causal relationship between GNP and energy consumption. Thus, their results tend to support the findings of Arkaca and Long.

Yu and Choi (1985) extended the analysis of Yu and Hwang in two directions. First, the causal relationship between GNP and energy was examined from an international perspective. Five countries in various stages of economic development were selected for the purpose of comparison and generalization. Second, the causal linkages between GNP and the aggregate and several disaggregate categories of energy consumption were studied, including solid fuels, liquid fuels, natural gas and others (such as hydro and nuclear). They found that the relationship between energy and GNP varies among countries, and the results of causality tests are fairly sensitive to samples. Therefore, it is not quite clear as yet whether the question of causality between energy and GNP has been settled or if the direction of the causality has been ascertained. The debate about the precise role of energy in economic development remains contentious at best, and many other studies have since followed.

Ebohon (1996) examined the causal direction between energy consumption and economic growth in two developing countries, Nigeria and Tanzania, using regression techniques. The results from this study show a 
simultaneous causal relationship between energy and economic growth for both countries, implying that if energy supply constraints are not relaxed, economic growth and development will remain elusive for these countries and other developing countries with similar economic characteristics.

Masih and Masih (1996) illustrated how the finding of cointegration - the long term equilibrium relationship- between energy consumption and economic growth may be used in testing Granger causality. They tested for cointegration between total energy consumption and real income for six countries: India, Pakistan, Malaysia, Singapore, Indonesia and the Philippines. Results based on the tools of methodology used in the study indicate that while all pair-wise relationships shared common univariate integrational properties, only relationships for India, Pakistan, and Indonesia were cointegrated. They found that for these 3 countries, temporal causality results imply at least one-way Granger-causality, either unidirectional or bi-directional. Causality results were unidirectional from energy to income for India, exactly the reverse for Indonesia, and mutual causality for Pakistan. The simple bivariate vector- autoregressive models did not indicate any direction of causality for the non-integrated systems (Malaysia, Singapore, and Philippines).

Asafu-Adjaye (2000) examined the causal relationship between energy consumption and income for India, Indonesia, the Philippines, and Thailand, using cointegration and error- correction modeling techniques. The results indicate that in the short run, unidirectional Granger causality runs from energy to income for India and Indonesia, while bi-directional Granger causality runs from energy to income for Thailand and the Philippines, where energy, income and prices are mutually causal.

Ferguson, William and Hill (2000), studied the relationship between electricity use and economic development for over one hundred countries constituting over $99 \%$ of the global economy. They concluded that wealthy nations have a stronger correlation between electricity use and wealth creation than do poor countries. Also, for the global economy as a whole, there is a stronger correlation between electricity use and wealth creation than there is between total energy use and wealth. And, in wealthy countries, the increase in wealth over time correlates with an increase in the proportion of energy that is used in the form of electricity.

From this, Ferguson et al., suggested that their research does not prove that there is a causal relationship between electricity use and economic development. However, they concluded that the study does show that in the technological world of the $20^{\text {th }}$ century, economic development occurred "hand in hand" with electricity consumption and, in particular, with an increase in the proportion of energy used in the form of electricity.

These results suggest that the relationship with wealth creation would be more appropriately attributed to electricity consumption than energy use in general. Thus, they also imply that the energy ratio should be replaced by the electricity ratio as a development indicator.

Yang (2000) examined the causal relationship between energy consumption and GDP using updated Taiwan data for the period 1954 - 1997. Applying Granger's (1969) technique, this study found bi-directional causality between total energy consumption and GDP. The study also found that different directions of causality exist between GDP and various forms of energy consumption. These results imply that causality not only depends on the type of energy source available, which also implies the level of economic development of the country, but also on the analytical method employed.

Soytas and Sari ( 2003) reexamined the causal relationship between energy consumption and income, using time series properties of energy consumption and GDP in the top 10 emerging markets- excluding China, and G-7 countries, 16 countries in all. They found bi-directional causality in Argentina. They also found causality running from GDP to energy consumption in Italy and Korea, and from energy consumption to GDP in Turkey, France, Germany, and Japan. Hence, energy conservation may harm economic growth in the last four counties.

Recently, Oh and Lee (2004) investigated the causal relationship between energy consumption and economic growth in Korea, applying a multivariate model of capital, labor, energy and GDP, to test for Granger causality in the presence of cointegration among variables. They employed a vector error correction (VECM) model rather than a 
vector autoregressive (VAR) model. Empirical results for Korea over the period 1970-1999 suggested a long run bidirectional causal relationship between energy and GDP, and short-run unidirectional causality running from energy to GDP and the source of causation in the long run was found to be the error correction terms in both directions.

Oh and Lee (2004) continued their investigation for Korea on the causal relationship between energy consumption and economic growth, applying two multivariate time series models, testing for Granger causality and also employing a VECM model. This study covered a different time period, $1981-2000$. The results suggested no causality between energy and GDP in the short run, and a unidirectional causal relationship running from GDP to energy in the long run.

Paul, S. and Bhattacharya, R. (2004) examined different directions of the causal relation between energy consumption and economic growth in India. They applied Engel-Granger cointegration approach combined with the standard Granger causality test on Indian data from 1950 - 1996. The results show that bi-directional causality exists between energy consumption and economic growth. They further applied the Johnson multivariable cointegration technique on a different set of variables and found the same bi-directional causality between energy consumption and economic growth. However, the authors noted that the results here obtained differed from results obtained from earlier studies. This implies that the technique used, and the time period investigated can matter greatly in the results obtained.

The table below presents a summary of the directions of causation for the countries discussed in the literature surveyed above.

\section{Analysis Of Findings}

\begin{tabular}{llll}
\hline GDP To Energy & Energy To GDP & Bi-Causality & Non-Causality \\
United States & India & Argentina & United States \\
Indonesia & Indonesia & Nigeria & Malaysia \\
Italy & Philippines & Tanzania & Singapore \\
Korea & Thailand & Pakistan & Philippines \\
& Turkey & Malaysia & \\
& Korea & Korea & \\
& France & India & \\
& Germany & Taiwan & \\
& Japan & & \\
\hline
\end{tabular}

This table shows that although energy consumption and economic development are related, the direction of causality is not fixed or permanent. Causality varies from one country to another, and is related to time and other economic factors. Causality also depends on the stage of economic development of a country, and the structure of the economy. In addition, as can be observed from the table, causality can change with time within a country as exemplified by the U.S., Indonesia, Malaysia, Philippines, Korea and India. Finally, the methodology and analytical technique employed also influence the results obtained on the direction of causation.

\section{ANALYSIS OF DATA FOR THE U.S.A.}

\section{Sources Of Data}

The data used in this study was obtained from two main sources. The data for the real gross domestic product came from the U.S. Department of Commerce, Bureau of Economic Analysis, NIPA Tables. The GDP is expressed in billions of dollars, and the year 2000 chained index was chosen. Energy consumption data was obtained from the U.S. Department of Energy, Energy Information Administration (EIA). Total energy consumption per year was used in this 
study and there was no decomposition into various forms of energy. Energy units are expressed in quadrillion BTUs per year.

\section{ENERGY-GDP RELATIONSHIP IN THE U.S. ECONOMY}

The recent increase in oil prices has engendered much debate about the long term impact on the U.S. economy. Many fear that a continued rise in oil prices and higher energy bills may eventually put a drag on the economy.

One main issue of concern and interest is inflation. In July, 2005, U.S. wholesale prices jumped 1\%, boosted by a surge in the cost of cars, and energy. Many people are concerned that higher oil prices will result in higher inflation. This is because oil is a fungible, strategic commodity. Oil is very important because it is used in various forms and for different purposes. Crude petroleum is an important resource for making a variety of products including fuels for transportation, tires, plastics, cosmetics, chemicals, shoes, synthetic rubber, industrial fabrics used for making tents and diapers, materials used in making toys and dolls, and so on. Therefore, as the price of oil rises, the cost of making products also rise, resulting in inflation. So inflation is the time period during which the general price level (the average of all prices for all goods and services in the economy) is on the rise.

This article focuses on the impact of rising oil prices on the overall U.S. economy as represented by the gross domestic product, GDP. The GDP measures the total market value of all final goods and services produced within the country over a given time period. Nominal GDP is measured in current dollars, also known as today's dollars. It is common practice to convert nominal GDP to real or constant GDP, by adjusting the nominal GDP for inflation. Therefore, the difference between nominal GDP and real GDP is inflation. In other words, nominal GDP represents values that have not been adjusted for inflation, while real GDP represents values that have been adjusted for inflation.

There is a strong relationship between energy consumption and real GDP. Energy availability and consumption play a key role in the process of economic development. Energy use has been associated with population growth and the expansion of urban enters. Energy use is a key to industrialization and the development of industrial infrastructural facilities. Roads and transportation networks are among the most energy intensive of these facilities. Energy use is a function of, and a consequence of economic growth.

In analyzing the impact of rising oil prices on the U.S. economy, history might lend a hand. The graph below depicts the historical relationship between total energy consumption and real GDP in the United States from1949 to 2003. The real GDP is expressed in billions of dollars, while total energy consumption is in quadrillion BTU's. The dots on the graph represent each of the years indicated, from left to right.

The graph shows that there was a smooth linear relationship between real GDP and total energy consumption from 1949 to 1974, except for the blip that can be observed around 1951 - 1953. Otherwise, it shows that from 1949 1974, both real GDP and total energy consumption were rising. During this period, economic growth, expressed as an increase in real GDP over time, required the consumption of more energy units.

The first break in this trend occurred in 1974, as the curve began to shift or move to the left in 1975 and 1976. This leftward shift of the curve implicates an obvious reaction or responsiveness to the rising oil prices that resulted from the Arab oil embargo of that era. More importantly, the data over the three year period (1974 - 1976), shows that approximately the same amount of economic activity (real GDP) was generated with less energy consumption, as a result of this responsiveness to higher oil prices. Although the real GDP did not rise over the said three year period, it did not show any declines. Thus, economic welfare was not reduced over this period. Rather, real gains were made by reducing energy intensity; the amount of energy required to produce a dollar of income (real GDP). Energy intensity is also called the energy-GDP ratio. 
Figure 1. U.S.A. Real GDP v. Energy Consumption (EC) 1949-2003

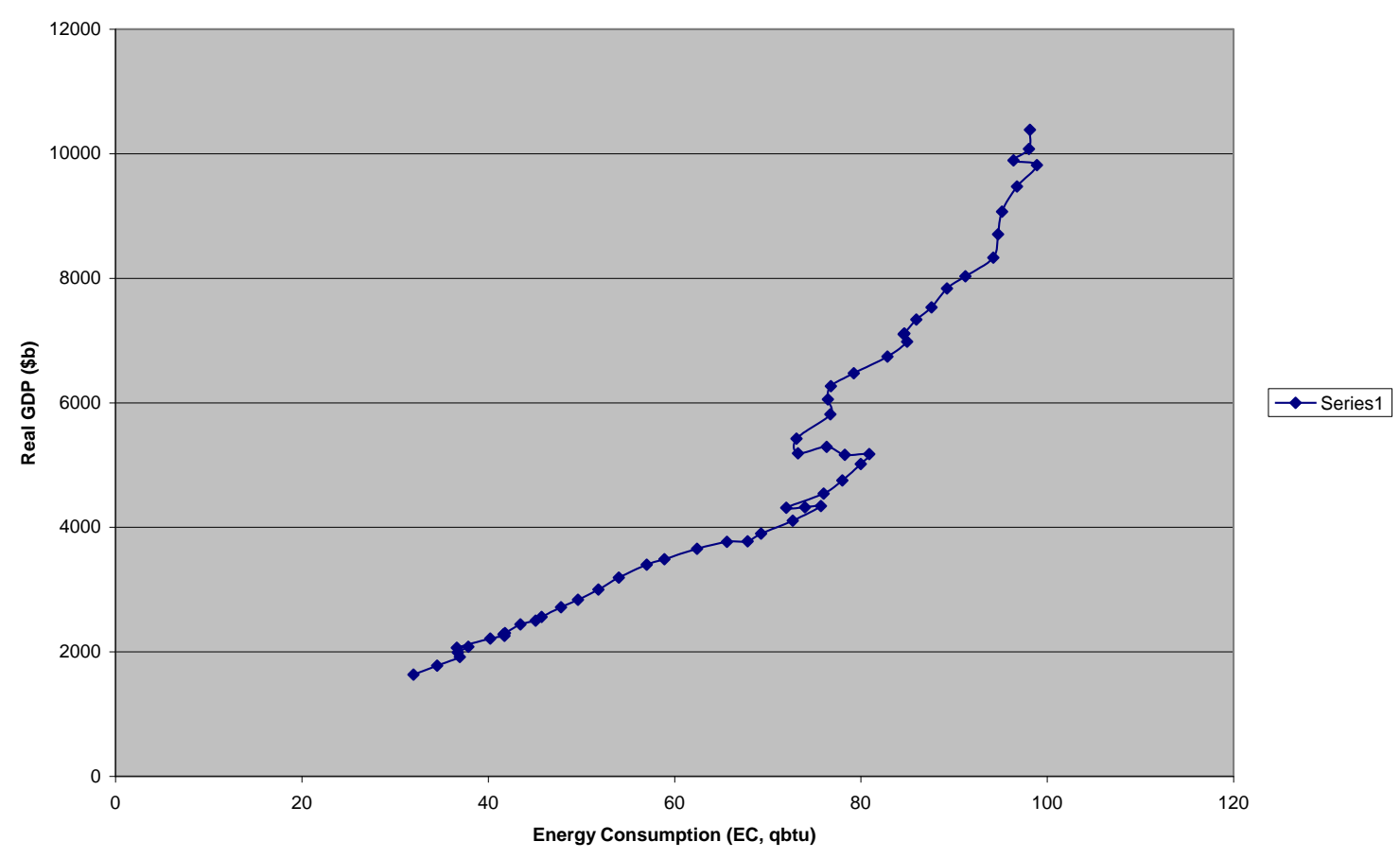

The graph then shows a new linear trend that ran from 1976 to 1980 . During this time, real GDP was rising with higher levels of energy consumption. This new trend stopped in 1980, when the curve began a new movement to the left. This shift was similar to the previous one but lasted a little longer till 1983. This new reaction was a response to the Iranian oil crisis of 1979/80, during which time oil prices were on the rise. As before, this leftward shift shows that the U.S. was able to maintain approximately the same level of real GDP with less energy consumption. There was no significant reduction in real GDP, no loss in economic welfare, but the amount of energy consumed went down. Many analysts may argue that there was economic stagnation because of the lack of growth in the GDP over the said period, but we should bear in mind that the worst case would be for real GDP to actually decline while total energy consumption is rising, a southeast movement of the graph. This worst case scenario has not been observed for the U.S.

These leftward shifts in the graph represented responses to high oil prices. Therefore, we can see so far that the U.S. economy reacted to higher oil prices in the past by consuming less energy at the same level of output. This is an improvement in energy use efficiency and a decline in energy intensity, which represents a reduction in the amount of energy required to produce a unit of real GDP. The goal of society is to be more energy efficient and the societal objective is to be less energy intensive at all times. In this case, society would desire to produce more income with less materials and energy. Consequently, over a long period of time, energy intensity will imply efficiency in energy consumption.

Further analysis of the graph shows that subsequent to 1983, the curve began a new trend, tending more vertical, till 1987. In fact, the curve moved vertically from 1983 - 1984, and from 1985 - 1987. These vertical movements indicate higher levels of economic activity with proportionally the same amount of energy consumption. This is an obvious improvement in energy intensity spurred by relatively rising oil prices.

From 1987 - 1996, the curve actually showed a new trend, a rightward but vertically tending movement, showing higher economic activity (real GDP) with higher levels of energy consumption. It is important to see that the overall relationship at this point is tending more vertical. The rightward trend over this period can be explained by the 
major crash in oil prices that occurred in 1986. Hence, as energy units became cheaper over this period, it encouraged more energy consumption which reduced efficiency.

Beyond 1996, the curve continued to take on a more vertical shape, a very significant development. This vertical tendency of the graph since 1996 is an indication of higher real GDP growth with the same and sometimes less amount of energy consumed. This new vertical trend indicates a major reduction in energy intensity, the amount of energy consumed per dollar of income or output. Overall, the graph shows that in the U.S., there is significant reaction or response to rising oil prices. On the average, the results from $1949-2003$, show a general vertical trend, indicating the ability to generate more economic growth with fewer energy units. .

Now, what can we learn from this graph to help us in predicting the effect of the current high oil prices on the U.S. economy? First, if history repeats itself, then we should expect another round of adjustments in the energy consumption/real GDP relationship, and a leftward shift of this graph in the future. It is likely that due to technological advancements, innovation, and energy conservation policies, the U.S. economy can adjust to higher oil process with better energy use efficiency. We can also conclude that the U.S. economy is capable of absorbing these higher oil prices and there will not be a significant negative welfare impact (declining real GDP amidst rising total energy consumption) in the economy. However, the history of the energy consumption/real GDP relationship in the U.S. shows that real GDP will remain flat for a few years, beginning from approximately one year after the start of serious rises in oil prices; the leftward shift of the graph.

On the other hand, the graph may be relating other important messages. A general interpretation of the overall graph shows differences in the slopes of the various trends described above. Prior to 1974, the trend was initially flatter. The flatter the trend, the more elastic it is, suggesting greater levels of responsiveness to changes in market factors, for example oil prices. However, the recent vertical trend exhibit an inelastic behavior. The more vertical, hence the steeper the trend, the more inelastic is the relationship. The more inelastic the trend, the less is the level of responsiveness to changes in market factors. This vertical tendency may represent a limiting ability to respond to market changes. We may be approaching the limits of our ability to respond to higher oil prices.

No one knows for sure right now what the future holds. It is quite possible that the response to the current rising oil prices may be unlike the previous responses. We can end up with a new or different type of adjustment, because 1974 to 1980 were quite close in time, six years apart. It is very feasible for the reactions to have been similar then. In the early days, the industrialized economies were built on the notion of cheap oil. So the oil shocks of the 1970's and 1980's were surprises. Today, high oil price is a fact of life. In 1974 and 1980, there were no cell-phones and e-mails, PCs, the Internet and all these modern hookup and communications facilities. We live in a different world now and it's been more than twenty years since the last oil price shocks, a new and different era.

As a result of the global economy that we live in today, there is persistent downward pressure on prices that is keeping inflation tame. Therefore, one possible response to the current rise in oil prices is that the graph above may not shift directly to the left as before. Rather, the graph will take a northwesterly trend, whereby real GDP is rising (rather than flat) while total energy consumption is declining. In other words, the graph will continue its vertical tendency in a leftward direction, as opposed to shifting directly left.

This anticipated response will also result from improvements and innovations in technology, improved energy use efficiency, energy conservation policies, options for alternative energy sources and the influence of a global economy.

\section{THE MODEL}

In this section we present the macroeconomic model which we will use to attempt to determine the relationship between energy consumption and GDP. Recall (see, for example, Henderson and Quandt, (1980)) that the utility maximizing consumer and the profit maximizing firm can, in each market, choose price or quantity. We suppose that firms and consumers choose either supply price or demand price in each market. Then, in an economy with taxation $(T)$, and with markets for energy used by consumers $\left(E_{1}\right)$, other consumer goods and services (C), 
energy used in production by firms $\left(\mathrm{E}_{2}=\mathrm{E}-\mathrm{E}_{1}\right.$ where $\mathrm{E}$ denotes total energy use), new plant and equipment $(\mathrm{dK})$, intermediate goods (I), saving (S), labor (L), Imports (Im), and exports (x), we have:

(1) a) $\quad p_{E 1}{ }^{d}=f_{1}\left(E_{1}, C, S, T, L, I m, x\right)$

b) $\quad \mathrm{p}_{\mathrm{E} 1}^{\mathrm{s}}=\mathrm{g}_{1}\left(\mathrm{E}_{1}, \mathrm{C}, \mathrm{E}_{2}, \mathrm{dK}, \mathrm{I}, \mathrm{S}, \mathrm{L}, \mathrm{Im}, \mathrm{x}\right)$

(2) a) $\quad \mathrm{p}_{\mathrm{c}}{ }^{\mathrm{d}}=\mathrm{f}_{2}\left(\mathrm{E}_{1}, \mathrm{C}, \mathrm{S}, \mathrm{T}, \mathrm{L}, \mathrm{Im}, \mathrm{x}\right)$

b) $\quad \mathrm{p}_{\mathrm{c}}{ }^{\mathrm{s}}=\mathrm{g}_{2}\left(\mathrm{E}_{1}, \mathrm{C}, \mathrm{E}_{2}, \mathrm{dK}, \mathrm{I}, \mathrm{S}, \mathrm{L}, \mathrm{Im}, \mathrm{x}\right)$

(3) a) $\quad \mathrm{p}_{\mathrm{E} 2}{ }^{\mathrm{d}}=\mathrm{f}_{3}\left(\mathrm{E}_{1}, \mathrm{C}, \mathrm{E}_{2}, \mathrm{dK}, \mathrm{I}, \mathrm{S}, \mathrm{L}, \mathrm{Im}, \mathrm{x}\right)$

b) $\quad \mathrm{p}_{\mathrm{E} 2}^{\mathrm{s}}=\mathrm{g}_{3}\left(\mathrm{E}_{1}, \mathrm{C}, \mathrm{E}_{2}, \mathrm{dK}, \mathrm{I}, \mathrm{S}, \mathrm{L}, \mathrm{Im}, \mathrm{x}\right)$

(4) a) $\quad \mathrm{p}_{\mathrm{dK}}{ }^{\mathrm{d}}=\mathrm{f}_{4}\left(\mathrm{E}_{1}, \mathrm{C}, \mathrm{E}_{2}, \mathrm{dK}, \mathrm{I}, \mathrm{S}, \mathrm{L}, \mathrm{Im}, \mathrm{x}\right)$

b) $\quad \mathrm{p}_{\mathrm{dK}}^{\mathrm{s}}=\mathrm{g}_{4}\left(\mathrm{E}_{1}, \mathrm{C}, \mathrm{E}_{2}, \mathrm{dK}, \mathrm{I}, \mathrm{S}, \mathrm{L}, \mathrm{Im}, \mathrm{x}\right)$

(5) a) $\quad \mathrm{p}_{\mathrm{I}}^{\mathrm{d}}=\mathrm{f}_{5}\left(\mathrm{E}_{1}, \mathrm{C}, \mathrm{E}_{2}, \mathrm{dK}, \mathrm{I}, \mathrm{S}, \mathrm{L}, \mathrm{Im}, \mathrm{x}\right)$

b) $\quad \mathrm{p}_{\mathrm{I}}^{\mathrm{s}}=\mathrm{g}_{5}\left(\mathrm{E}_{1}, \mathrm{C}, \mathrm{E}_{2}, \mathrm{dK}, \mathrm{I}, \mathrm{S}, \mathrm{L}, \mathrm{Im}, \mathrm{x}\right)$

(6) a) $\quad \mathrm{w}^{\mathrm{d}}=\mathrm{f}_{6}\left(\mathrm{E}_{1}, \mathrm{C}, \mathrm{E}_{2}, \mathrm{dK}, \mathrm{I}, \mathrm{S}, \mathrm{L}, \mathrm{Im}, \mathrm{x}\right)$

b) $\quad \mathrm{w}^{\mathrm{s}}=\mathrm{g}_{6}\left(\mathrm{E}_{1}, \mathrm{C}, \mathrm{S}, \mathrm{T}, \mathrm{L}, \mathrm{Im}, \mathrm{x}\right)$

(7) a) $\quad r^{d}=f_{7}\left(E_{1}, C, E_{2}, d K, I, S, L, I m, x\right)$

b) $\quad r^{\mathrm{s}}=\mathrm{g}_{7}\left(\mathrm{E}_{1}, \mathrm{C}, \mathrm{E}_{2}, \mathrm{dK}, \mathrm{I}, \mathrm{S}, \mathrm{L}, \mathrm{Im}, \mathrm{x}\right)$

(8) a) $\quad \mathrm{p}_{\mathrm{im}}{ }^{\mathrm{d}}=\mathrm{f}_{8}\left(\mathrm{E}_{1}, \mathrm{C}, \mathrm{E}_{2}, \mathrm{dK}, \mathrm{I}, \mathrm{S}, \mathrm{L}, \mathrm{Im}, \mathrm{x}\right)$

b) $\quad \mathrm{p}_{\mathrm{im}} \mathrm{s}=\mathrm{g}_{8}($ Index $)$

(9) a) $\quad \mathrm{p}_{\mathrm{x}}{ }^{\mathrm{d}}=\mathrm{f}_{9}($ Index $)$

b) $\quad \mathrm{p}_{\mathrm{x}}^{\mathrm{s}}=\mathrm{g}_{9}\left(\mathrm{E}_{1}, \mathrm{C}, \mathrm{E}_{2}, \mathrm{dK}, \mathrm{I}, \mathrm{S}, \mathrm{L}, \mathrm{Im}, \mathrm{x}\right)$

Now, setting demand price equal to supply price in (1), (2), (4), (5), (7), (8), and (9), and then solving the resulting expressions for $\mathrm{E}_{1}, \mathrm{C}, \mathrm{dK}, \mathrm{I}, \mathrm{S}, \mathrm{Im}$, and $\mathrm{x}$, we obtain the following "semi-reduced forms" (see McCallum (1974)):

(11) $\mathrm{dK}=\mathrm{h}_{3}\left(\mathrm{E}_{2}, \mathrm{~L}\right)$

(12) $\quad \mathrm{I}=\mathrm{h}_{4}\left(\mathrm{E}_{2}, \mathrm{~L}, \mathrm{C}\right)$

(13) $\mathrm{S}=\mathrm{h}_{5}\left(\mathrm{E}_{2}, \mathrm{~L}, \mathrm{C}\right)$

(14) $\quad \operatorname{Im}=h_{6}\left(E_{2}, L, C\right)$

(15) $\quad \mathrm{x}=\mathrm{h}_{7}\left(\mathrm{E}_{2}, \mathrm{~L}, \mathrm{C}\right)$

Since we do not have observations on $E_{1}$ and $E_{2}$, we will use the Kalman Filter to infer what the values of $E_{2}$ must have been (in conjunction with the behavior of the other variables in our system) to have caused the values of $C$, $\mathrm{dK}$, I, and $\mathrm{x}$ which we actually observe. To do this, we need two sets of equations. First, we need an equation (or set of equations) to describe the behavior of the unobservable variable(s). In this case we use

$$
\begin{aligned}
& \mathrm{E}_{2}(\mathrm{t}+1)-\mathrm{E}_{2}(\mathrm{t})=\mathrm{b}_{0}\left(\mathrm{E}_{1}(\mathrm{t}+1)-\mathrm{E}_{1}(\mathrm{t})\right)+\mathrm{b}_{1}(\mathrm{C}(\mathrm{t}+1)-\mathrm{C}(\mathrm{t}))+\mathrm{b}_{2}(\mathrm{dK}(\mathrm{t})-\mathrm{dK}(\mathrm{t}-1))+\mathrm{b}_{3}(\mathrm{I}(\mathrm{t}+1)-\mathrm{I}(\mathrm{t}))+\mathrm{b}_{4}(\mathrm{x}(\mathrm{t}+1)- \\
& \mathrm{x}(\mathrm{t}))+\mathrm{b}_{5}(\mathrm{~L}(\mathrm{t}+1)-\mathrm{L}(\mathrm{t}))
\end{aligned}
$$


Since $\mathrm{E}_{1}=\mathrm{E}-\mathrm{E}_{2}$, we can make this substitution and then solve for $\mathrm{E}_{2}(\mathrm{t}+1)$, obtaining

$$
\begin{aligned}
& \mathrm{E}_{2}(\mathrm{t}+1)=\mathrm{E}_{2}(\mathrm{t})+\mathrm{c}_{1}(\mathrm{C}(\mathrm{t}+1)-\mathrm{C}(\mathrm{t}))+\mathrm{c}_{2}(\mathrm{dK}(\mathrm{t})-\mathrm{dK}(\mathrm{t}-1))+\mathrm{c}_{3}(\mathrm{I}(\mathrm{t}+1)-\mathrm{I}(\mathrm{t}))+\mathrm{c}_{4}(\mathrm{x}(\mathrm{t}+1)-\mathrm{x}(\mathrm{t}))+\mathrm{c}_{5}(\mathrm{~L}(\mathrm{t}+1)- \\
& \mathrm{L}(\mathrm{t}))+\mathrm{c}_{0}(\mathrm{E}(\mathrm{t}+1)-\mathrm{E}(\mathrm{t})) \\
& \mathrm{c}_{\mathrm{i}}=\mathrm{b}_{\mathrm{i}} /\left(1-\mathrm{b}_{0}\right) \quad \mathrm{i}=0,1,2,3,4,5
\end{aligned}
$$

This is essentially a production function: amount of energy used depends upon amounts of outputs produced and amount of other inputs used. Second, we need a set of equations to relate the unobservable variables to the observable variables. In this case we use

$$
\begin{aligned}
& \left.E_{1}(t)=f_{11} E_{2}(t)+f_{12} L(t)\right)+f_{13} C \\
& \left.d K(t)=f_{21} E_{2}(t)+f_{22} L(t)\right)+f_{23} C \\
& \left.I(t)=f_{31} E_{2}(t)+f_{32} L(t)\right)+f_{33} C \\
& \left.x(t)=f_{41} E_{2}(t)+f_{42} L(t)\right)+f_{43} C
\end{aligned}
$$

If we express (17) and (18) in matrix form:

$$
\begin{aligned}
& \mathrm{E}_{2}(\mathrm{t}+1)=\mathrm{AE}_{2}(\mathrm{t})+\mathrm{Cv}(\mathrm{t})+\mathrm{m}(1) \\
& \mathrm{Z}(\mathrm{t})=\mathrm{FE}_{2}(\mathrm{t})+\mathrm{Du}(\mathrm{t})+\mathrm{m}(2)
\end{aligned}
$$

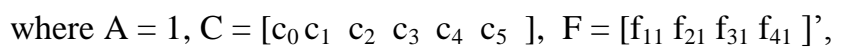

$$
\begin{aligned}
& \mathrm{D}=\left[\begin{array}{ll}
\mathrm{f}_{12} & \mathrm{f}_{13}
\end{array}\right] \\
& {\left[\begin{array}{ll}
f_{22} & f_{23}
\end{array}\right]} \\
& {\left[\begin{array}{ll}
f_{32} & f_{33}
\end{array}\right]} \\
& {\left[\begin{array}{ll}
f_{42} & f_{43}
\end{array}\right]}
\end{aligned}
$$

and

$\mathrm{v}(\mathrm{t})=[(\mathrm{C}(\mathrm{t}+1)-\mathrm{C}(\mathrm{t}))(\mathrm{dK}(\mathrm{t})-\mathrm{dK}(\mathrm{t}-1))(\mathrm{I}(\mathrm{t}+1)-\mathrm{I}(\mathrm{t}))(\mathrm{x}(\mathrm{t}+1)-\mathrm{x}(\mathrm{t}))(\mathrm{L}(\mathrm{t}+1)-\mathrm{L}(\mathrm{t}))(\mathrm{E}(\mathrm{t}+1)-\mathrm{E}(\mathrm{t}))] \mathrm{u}(\mathrm{t})=\mathrm{L}(\mathrm{t})$

and where $\mathrm{m}(1)$ and $\mathrm{m}(2)$ are vectors of random disturbances, then the Kalman Filter expression becomes:

$$
\mathrm{E}_{2} *(\mathrm{t}+1)=\mathrm{E}_{2} *(\mathrm{t})+\mathrm{Cv}(\mathrm{t})+\mathrm{K}(\mathrm{t})\left\{\mathrm{Z}(\mathrm{t})-\mathrm{FE}_{2} *(\mathrm{t})-\mathrm{Du}(\mathrm{t})\right\}
$$

When we use Multiple Model Estimation (see Appendix) to obtain estimates of the mean values of system parameters (expressed in logarithmic form), we find that:

- $\quad$ A mean increase in energy use of $1.86 \%$ is needed to bring about a $1 \%$ increase in $\mathrm{dK}(\mathrm{t})$ production (see $\mathrm{f}_{21}$ in the logarithmic version of the $\left.d K(t)=f_{21} E_{2}(t)+f_{22} L(t)\right)+f_{23} C$ equation)

- $\quad$ A mean increase in energy use of $1.14 \%$ is required to ring about a $1 \%$ increase in $\mathrm{I}(\mathrm{t})$ production (see $\mathrm{f}_{31}$ in the logarithmic version of the $\left.I(t)=f_{31} E_{2}(t)+f_{32} L(t)\right)+f_{33} C$ equation)

- A mean increase in energy use of $1.78 \%$ is required to bring about a $1 \%$ increase in $x(t)$ production (see $\mathrm{f}_{41}$ in the logarithmic version of the $\left.x(t)=f_{41} E_{2}(t)+f_{42} L(t)\right)+f_{43} C$ equation)

- $\quad$ The energy required per unit of $\mathrm{dK}(\mathrm{t}), \mathrm{I}(\mathrm{t})$, and $\mathrm{x}(\mathrm{t})$ has decreased over the sample period: US firms have become more energy efficient.

- $\quad$ The energy (i.e., $E_{1}$ ) demanded per unit of per capita consumption (see the $\left.E_{1}(t)=f_{11} E_{2}(t)+f_{12} L(t)\right)+f_{13} C$ equation) has increased steadily over the sample period. The US consumer has become less energy efficient

Since Multiple Model Estimation is a Bayesian procedure, no standard errors can be computed, and no hypothesis tests are done 
To summarize, our model suggests that causation goes both ways: from energy to the components of GDP, from GDP to energy consumption. In addition, our model suggests that producers are becoming more energy efficient, while consumers are becoming less so. Thus, we expect $\mathrm{E}_{1}$ to grow over time as a proportion of $\mathrm{E}$, while we expect $\mathrm{E}_{2}$ to shrink.

\section{Appendix \\ Multiple Model Estimation}

Stengel (1986) suggests that we find the parameter vector which best estimates the true parameter vector by using the following Bayesean procedure:

1. Pick k different sets of parameter vectors, $\theta_{1}, \theta_{2}, \ldots, \theta_{\mathrm{K}}$, and assign each vector an initial probability of being the correct parameter vector (e.g., let each have prior probability $1 / \mathrm{K}$ )

2. Choose the form $\mathrm{p}\left(\mathrm{z}(\mathrm{t}) \mid \theta_{\mathrm{k}}\right)$ of the likelihood function for $\mathrm{z}(\mathrm{t})$, given particular parameter vector $\theta_{\mathrm{k}}, \mathrm{k}=1,2$, $\ldots, \mathrm{K}$

3. Evaluate each $\mathrm{p}\left(\mathrm{z}(\mathrm{t}) \mid \theta_{\mathrm{k}}\right)$ at $\mathrm{z}(1)$, the first observed value of $\mathrm{z}(\mathrm{t})$. Use this observed value to evaluate

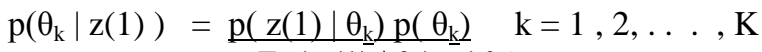

$$
\begin{aligned}
& \Sigma \mathrm{p}\left(\mathrm{z}(1) \mid \theta_{\mathrm{k}}\right) \overline{\mathrm{p}}\left(\theta_{\mathrm{k}}\right)
\end{aligned}
$$

4. Repeat 3, using $\mathrm{p}\left(\theta_{\mathrm{k}} \mid \mathrm{z}(1)\right)$ instead of $\mathrm{p}\left(\theta_{\mathrm{k}}\right)$ as the "prior", obtaining

$$
\mathrm{p}\left(\theta_{\mathrm{k}} \mid \mathrm{z}(1), \mathrm{z}(2)\right)=\frac{\mathrm{p}\left(\mathrm{z}(2) \mid \theta_{\mathrm{k}}\right) \mathrm{p}\left(\theta_{\mathrm{k}} \mid \mathrm{z}(1)\right)}{\Sigma \mathrm{p}\left(\mathrm{z}(1) \mid \theta_{\mathrm{k}}\right) \mathrm{p}\left(\theta_{\mathrm{k}} \mid \mathrm{z}(1)\right.} \mathrm{k}=1,2, \ldots, \mathrm{K}
$$

5. Proceed through the data set repeating step 4, until

$\mathrm{p}\left(\theta_{\mathrm{k}} \mid \mathrm{z}(1), \mathrm{z}(2), \mathrm{z}(3), \ldots, \mathrm{z}(\mathrm{n})\right)$ is obtained

We can now use this probability density to find the mean value of the parameter vector,

$$
\theta_{\mathrm{k}}^{*}=\iint \ldots \int \theta_{\mathrm{k}} \mathrm{p}\left(\theta_{\mathrm{k}} \mid \mathrm{z}(1), \mathrm{z}(2), \mathrm{z}(3), \ldots, \mathrm{z}(\mathrm{n})\right) \mathrm{d} \theta_{\mathrm{K}} \ldots \mathrm{d} \theta_{2} \mathrm{~d} \theta_{1}
$$

To forecast $\mathrm{z}(\mathrm{t}+\mathrm{s})$, notice that

$$
\mathrm{p}\left(\mathrm{z}(\mathrm{t}+\mathrm{s}), \theta_{\mathrm{k}} \mid \mathrm{z}(1), \ldots \mathrm{z}(\mathrm{n})\right)=\mathrm{p}\left(\mathrm{z}(\mathrm{t}+\mathrm{s}), \theta_{\mathrm{k}} \mid \mathrm{z}(1), \ldots \mathrm{z}(\mathrm{n})\right) \mathrm{p}\left(\theta_{\mathrm{k}} \mid \mathrm{z}(1), \ldots \mathrm{z}(\mathrm{n})\right)
$$

so that

$$
\mathrm{p}(\mathrm{z}(\mathrm{t}+\mathrm{s}) \mid \mathrm{z}(1), \ldots \mathrm{z}(\mathrm{n}))=\iint \ldots \int \mathrm{p}\left(\mathrm{z}(\mathrm{t}+\mathrm{s}), \theta_{\mathrm{k}} \mid \mathrm{z}(1), \ldots \mathrm{z}(\mathrm{n})\right) \mathrm{d} \theta_{\mathrm{K}} \ldots \mathrm{d} \theta_{2} \mathrm{~d} \theta_{1}
$$

Now the probability density of $\mathrm{z}(\mathrm{t}+\mathrm{s})$ can be used to make probability statements about the future behavior of $\mathrm{z}(\mathrm{t}+\mathrm{s})$

\section{REFERENCES}

1. Akarca, A. T. and Long, T.V. 1980. Notes and Comments on the Relationship between Energy and GDP. A Reexamination. Journal of Energy and Development (Spring): 326-331.

2. Asafu-Adjaye, J. 2000. The Relationship between Energy Consumption, Energy Prices and Economic Growth. Time Series Evidence From Asian Developing Countries. Energy Economics 22 (6): 615-625.

3. Darmstadter, J., Dunkerley, J., and Alterman, J. 1977. How Industrial Societies Use Energy. A Comparative Analysis. Published for Resources for the Future by the Johns Hopkins University Press. 
4. Ebohon, O. J. 1996. Energy, Economic Growth and causality in Developing Countries. A Case Study of Tanzania and Nigeria. Energy Policy 24 (3): 447-453.

5. Elias, J. and Grabik, W. 1980. A Comparison of Energy Consumption in Eastern and Western Europe. Energy Economics (October): 237-242.

6. Ferguson, R., Wilkinson, W., and Hill, R. 2000. Electricity Use and Economic Development. Energy Policy 28 (2000); 923-934.

7. Granger, C. W. J. 1969. Investigating Causal Relationships by Econometric Models and Cross-Spectral Methods. Econometrica 37 (3): 424-439.

8. http://www.bea.gov/bea/dn/nipaweb/table. National Income and Product Accounts Table

9. http://www.eia.doe.gov/emeu/aer/txt. Table 1.1 Energy Overview, 1949 - 2003

10. http://www.stls.frb.org. U.S Macroeconomic Data Set

11. Jones, D. W. 1991. How Urbanization Affects Energy-Use in Developing Countries. Energy Policy (September): 621-630.

12. Judson, R. A., Schmalensee, R., and Stoker, T. 1999. Economic Development and the Structure of the Demand for Commercial Energy. The Energy Journal 20 (2): pg.29.

13. Kraft, J. and Kraft, A. 1978. On the Relationship between Energy and GDP. Journal of Energy and Development (Spring): 401-403.

14. Masih, A. M. M. and Mansih R. 1996. Energy Consumption, Real Income and Temporal Causality: Results from a Multi-Country Study Based on Cointegration and Error-Correction Modeling Techniques. Energy Economics 18 (3): 165-183.

15. Medlock, K. B. and Soligo, R. 2001. Economic Development and End-Use Energy Demand. The Energy Journal 22 (2): pg.77.

16. Morimoto, R. and Hope, C. 2004. The Impact of Electricity Supply on Economic Growth in Sri Lanka. Energy Economics 26 (1): 77-85.

17. Murtishaw, S. and Schipper, L. 2001. Disaggregated Analysis of U.S. Energy Consumption in the 1990's: Evidence of the Effects of the Internet and Rapid Economic Growth. Energy Policy 29 (2001): 1335-1356.

18. Oh, W. and Lee, K. 2004. Causal Relationship between Energy Consumption and GDP Revisited: The Case of Korea 1970- 1999. Energy Economics 26 (1): 51-59.

19. Oh, W. and Lee, K. 2004. Energy consumption and economic growth in Korea: testing causality relation. Journal of Policy Modeling 26 (8, 9): 973

20. Paul, S. and Bhattacharya, R. N. 2004. Causality between energy consumption and economic growth in India: a note on conflicting results. Energy Economics 26 (6): 977

21. Pierce, W. S. 1986.b Economics of the Energy Industries. Belmont, Calif.: Wardsworth Publishing Co. 4354.

22. Sims, C. A. 1972. Money, Income, and Causality. American Economic Review (September): 540-552.

23. Soytas, U. and Sari, R. 2003. Energy Consumption and GDP: Causality Relationships in G-7 Countries and Emerging Markets. Energy Economics 25 (1): 33-37

24. Stengel, R. 1986. Optimal Control and Estimation. John Wily.

25. Tabti, M. T. and Mandi, W. 1985. Energy Indicators. OPEC Review 9 (Winter): 417-455.

26. Yang, H. Y. 2000. A note on the causal relationship between energy and GDO in Taiwan.: Energy Economics 22 (3): 309-317

27. Yu, E. S. and Hwang, B. 1984. The Relationship between Energy and GDP: Further Results. Energy Economics (July): 186-190.

28. Yu, E. S. and Choi, J. 1985. The causal Relationship between Energy and GDP: Am International Comparison Journal of Energy and Development (Spring): 249-271. 


\section{NOTES}

